\title{
Utilization Patterns of Urban Green Infrastructure in Southern Ethiopia
}

\author{
1, ${ }^{*}$ MOLLA, MB; ${ }^{2}$ IKPORUKPO, CO; ${ }^{3}$ OLATUBARA, CO \\ ${ }^{I}$ Pan-Africa University, Life and Earth Sciences Institute (including Health and Agriculture), ${ }^{2}$ Department of Geography, ${ }^{3}$ Department of Urban \\ and Regional Planning, University of Ibadan, Ibadan, Nigeria \\ ${ }^{4}$ Hawassa University, Wondo Genet College of Forestry and Natural Resources, P.O. Box 128, Shashemene, Ethiopia
}

\begin{abstract}
Urban green infrastructure provides multi-functional socio-economic and environmental benefits and promotes physical, relaxation, and the social activities of the urban residents. This paper analyses the pattern of utilization of urban green infrastructure in Southern Ethiopia. Data were collected using structured questionnaires, key informant interview and focus group discussion. The collected data also analysed using descriptive statistics and ANOVA. The majority $(78 \%)$ of the respondents visit green corridors in Hawassa. $68 \%$ of respondents visit parks in Wolayita Sodo, while, $62 \%$ of the respondents visited home garden in Bodity town. There is an overall significant $(0.000)$ variation in the utilization of green infrastructures among urban centres. Based on Post-Hoc Test there is a statistically significant $(p=0.017)$ difference in the utilisation of green infrastructure in between Hawassa city and Wolayita Sodo as well as between Hawassa and Bodity town $(p=0.000)$, but there was no significant $(p=0.113)$ difference between Wolayita Sodo and Bodity town. Majority (34.6\%, 31.6\% and 32.4\%) of respondents visit Lakeshore, Junior Park, and Bodity Stadium in Hawassa, Wolayita Sodo and Bodity town respectively. Green corridors in Hawassa, urban parks in Wolayita Sodo and Bodity Stadium in Bodity town was the most frequently visited GI types. Recreational, physical and social activities were the main reasons for visiting urban green infrastructure in the study area. The pattern of utilization of green infrastructure types varies significantly among the three urban centres. Urban planners, designers, and ecologists, therefore, need to focus on urban green infrastructure planning, strategies to promote the utilization of green infrastructure in the urban environment sustainably.
\end{abstract}

\section{DOI: https://dx.doi.org/10.4314/jasem.v21i7.1}

COPYRIGHT: Copyright (C) 2017 Molla et al. This is an open access article distributed under the Creative Commons Attribution License (CCL), which permits unrestricted use, distribution, and reproduction in any medium, provided the original work is properly cited

Keywords: Pattern of Utilization, Urban Green infrastructure, Visitors, Green /parks

Globally cities are becoming increasingly congested and polluted (Blanco et al., 2009; Maas et al., 2009; Ohta et al., 2007; Lee and Maheswaran, 2011; Saniya and Faria, 2013). Urban green infrastructure provides a wide range of socio-economic and environmental benefits that could help to improve the urban environment and life for city dwellers (Roy et al., 2012; Koizumi and Katayama, 1996; Hu and Tang, 2011; Wang, 2001; Katharine, 2009; Ward-Thompson et al, 2005). Normally, urban green spaces serve to beautify the city environment, purify air, and provide a place for residents to relax and enjoy (Blanco et al., 2009; Geis, 2000; Li et al., 2007). As Dahmann et al., (2010) reported that green infrastructure is diverse, varying in size, vegetation cover, species richness, environmental quality, proximity to public transport, facilities, and services (Fuller and Gaston, 200). As stated by Jerret (2010), Sister et al. (2010), and Jennifer et al. (2014), urban green infrastructure includes parks and reserves, sporting fields, green corridors (lake, stream, and river banks), greenways and trails, community gardens, street trees, and nature conservation areas, as well as less

*Corresponding author Email: mikiasmolla@gmail.com conventional spaces such as green walls, green alleyways, and cemeteries.

It clearly shows their importance is misunderstood and undermined in the debate about architecture and built environment. As a result, it strongly affects the pattern of visitors to parks and green areas in the case study area (Giles-Corti and Donovan, 2002; Giles-Corti et al., 2003; Veitch et al, 2012; Dunnett et al., 2002). Green infrastructures, if properly planned, managed and well connected with its surrounding area can improve the urban environment by enhancing community development, social cohesion and attract tourism investment (Barton and Pretty (2010; Lee's, 2001; Hague and Siegel, 2002; Milton, 2002; Takano et al. 2002; Jackson, 2003; Chiesura, 2004). Therefore, this study investigates the current situation of the utilization of urban green infrastructure at different hierarchy of urban centres. This study examines the variation in the utilization of green infrastructure development among the urban centres. The paper also suggested recommendations in the utilization and the pattern of visitors to visit green infrastructure. 


\section{MATERIALS AND METHODS}

Description of the study area: Three case study areas (Hawassa city, Wolayita Sodo and Bodity town) were purposively selected. The selection was done in consultation with the Regional Sanitation and Beautification Park Administration and Development Office. The first Case Study area was Hawassa city. It is the capital city of South Nation and Nationalities Peoples (SNNP) Regional State. The city is located between $37^{0} 52^{\prime}-39^{0} 11^{\prime}$ East longitude and $06^{\circ} 27^{\prime}-07^{0}$ $40^{\prime}$ North latitude with an elevation of 1708 meters above sea level (Figure 1). It is found at a distance of $275 \mathrm{~km}$ from Addis Ababa (capital city of Ethiopia) in the Southern part of the country, within the rift valley depression and bordered by Lake Hawassa. According to CSA (2007) report, Hawassa city accommodates 210,676 inhabitants. It covers 50.24 square kilometres and divided into eight sub-cities.

The land use of the city includes approximately $19.27 \%$ for residential area, $20.20 \%$ for transportation (road), $7.06 \%$ for commercial area, $2.10 \%$ for institution, $12.20 \%$ allocated for the social service area, $5.74 \%$ for production and selling area (marketing) area, $16.4 \%$ for green infrastructure (trees and forest) area, $4.03 \%$ allocated for mixed-use service area, $13.10 \%$ for other service area (World Bank, 2016). The city has a variety of tree and forest resources such as coniferous and broad-leaved (reserved) forest that are distributed according to its environmental condition. Such forest resources have a variety of potential and should be protected and reserved, as they could serve as an important base for development of the Region in general and the urban centres in particular (World Bank, 2016).

Wolayita Sodo Town was the second case study area. It is the administrative centre of Wolayita Zone of SNNPRS and found at a distance of $390 \mathrm{~km}$ from Addis Ababa and $167 \mathrm{~km}$ from the regional city Hawassa. The town is located at $6^{\circ} 54^{\prime} \mathrm{N}$ Latitude and $37^{\circ} 45^{\prime} \mathrm{E}$ Longitude with an elevation between 1600 to 2100 meters above sea level (Figure 1). According to CSA (2007), the total population of the town was 100,755 and the town has 25.62 square kilometre coverage, three sub-cities and 11 kebeles ${ }^{1}$.

The town is settled on naturally very undulating and mountainous topography/area and mostly exposed to high flood hazards and degradation of land soil erosion. The natural conditions facilitate diverse and fast vegetation growth and nurture a regional landscaping tradition (Wolayita Sodo Town Administration, 2014).

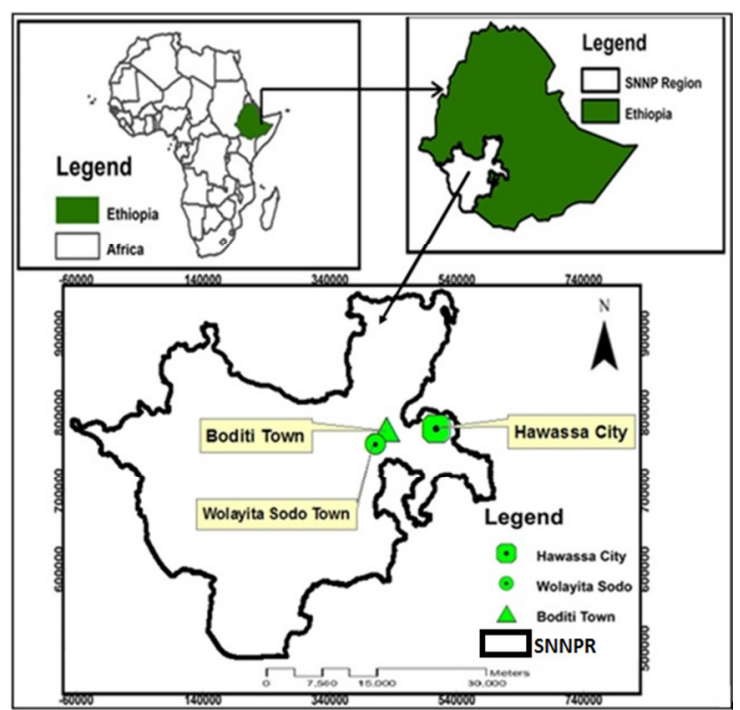

Fig 1: The Location of Sample City/Towns, Note: SNNPR means South Nation Nationalities and Peoples Region Source: Author

Bodity town was also the third case study site. It is a small emerging town under Wolayita Zone in SNNPRS. It is situated at $6^{\circ} 58^{\prime} \mathrm{N}$ latitude and $37^{\circ} 52^{\prime} \mathrm{E}$ longitude with an elevation of 2050 meters above sea level (Figure 1). The town is at a distance of $366 \mathrm{~km}$ from Addis Ababa and $153 \mathrm{~km}$ from regional city Hawassa. It is the administrative centre of Damot Gale Woreda. Based on figures from the CSA in 2007, the total population size of the town was 31, 973 and the town has its administration and municipality, has 6.16 square kilometre area coverage and divided into two sub-city and four kebeles.

Research design and Sampling techniques: The study employed a combination of both case study and crosssectional research designs to gather the required data. The cross-sectional approach was used to collect data using the questionnaire survey method. The regional and local urban green development officials were consulted in designing the questionnaire. Thus a total of 400 copies of structured questionnaires was administered to collect both qualitative and quantitative data. Qualitative methods encompass key informant interview, focus group discussion and physical observation using a video camera. While, the quantitative approach evaluated the socio-economic profile and monthly visit of green infrastructure, including gender, age, marital status, education level, household annual income, occupation, distance to reach the nearest green infrastructure. All questionnaire survey procedures were performed in compliance with relevant laws and institutional guidelines.

\footnotetext{
${ }^{1}$ Kebele is the lower administrative unit of the country.
} 
Multistage cluster sampling technique was employed to select the specific study area. After clustering the study area, any mature member of the household (age, >18) was selected using simple random sampling technique at each village. A questionnaire was administered based on the population proportion of each case study area. The target sample size of 400 was distributed using the simple random sampling technique in each case study area, based on population size. A pilot test (10\%) examined the logic, clarity, succinctness of the questions (Thomas et al., 2014).

Data Collection and Analysis Methods: Primary and secondary sources of data were used for this investigation. The primary data sources were key informant interview, focus group discussion, and household survey using structured questionnaires. While the secondary data sources were archival records and documentary data. A questionnaire survey, focus group discussion and key informant interview were used as the main data collection methods for this study. Focus Groups Discussion and Key Informants Interviews are important data sources to validate household survey results. The FGD's were used to collect utilization of urban green infrastructure development, people's involvement, and existing challenges in the utilization and management of green infrastructure. Thus, a total of nine focus group discusses was conducted in the entire study area. A total of 32 key informants were interviewed in the whole study area to gather information related to the utilization and management, the participation of communities in the utilization of green infrastructure.

Descriptive analysis and inferential statistics were used to analyse the collected data. Descriptive analysis methods were used to describe the frequency of score or recorded values. It was used to summarise the response of the residents (household) in the form of number or percentage. Inferential statistics were used to test the strength of the association between two categorical variables. Analysis of Variance (ANOVA) was used to test the variations in the utilisation of green infrastructure development.

\section{RESULTS AND DISCUSSION}

Utilization of Green Infrastructures: The analysis revealed that $78 \%$ of visitors visit green corridors such as lake shores in Hawassa city, followed by home garden (69\%) and outdoor sports fields (68\%) (Table 1). As Nigatu et al. (2014) describe, Lake Hawassa is one source of the city economy and recreational or tourist attraction area in Hawassa city. Similarly, the home garden has provided multi-functional benefit to the communities. While protected urban parks are also used for occasions and events as well as relaxation centres on weekends.

This is closely followed by green areas $(66 \%)$ protected urban parks (65), and city square and plazas (62\%). However, natural and semi-natural area, roadside green space, institutional compound and cemetery and religious yards have received lower visitors in the city. Thereby, $53 \%, 58 \%$ and $46 \%$ of the respondents utilised natural and semi-natural area, roadside green space, institutional compound and cemetery and religious yards relatively in Hawassa city. Studies conducted by Assefa et al. (2011) revealed that the utilisation of green infrastructure in Hawassa city was relatively better, but it has a lot of limitations on the proper utilisation of green spaces. In Wolayita Sodo town urban parks have very high $(68 \%)$ users, followed by outdoor sports field (59\% and green areas (58\%). Similarly, roadsides green spaces and home garden (home yards) were visited by $53 \%$ of respondents in the town (Wolayita Sodo Town Administration, 2015). But, the lower visiting response was registered in green corridors $(31 \%)$, institutional compound (35\%) and cemetery and religious yards (38\%) (Table 1).

Table 1: Types of green infrastructure frequently utilized (visited) by respondents

\begin{tabular}{|c|c|c|c|c|c|}
\hline \multirow{3}{*}{$\mathrm{S} / \mathrm{N}$} & \multirow{3}{*}{ Green infrastructure types } & \multicolumn{4}{|c|}{ No of Visitors by Urban Centre (n (\%)) } \\
\hline & & Hawassa & W-Sodo & Bodity & Total \\
\hline & & $\mathrm{n}(\%)$ & $\mathrm{n}(\%)$ & $\mathrm{n}(\%)$ & $\mathrm{n}(\%)$ \\
\hline 1 & Protected urban parks & $160(65)$ & $80(68)$ & $15(41)$ & $238(60)$ \\
\hline 2 & Green Areas & $162(66)$ & $68(58)$ & $12(32)$ & $242(61)$ \\
\hline 3 & Home Garden (home yards) & $169(69)$ & $62(53)$ & $23(62)$ & $254(64)$ \\
\hline 4 & City Square and plazas & $152(62)$ & $57(49)$ & $13(35)$ & $222(56)$ \\
\hline 5 & Green Corridors (river and lake) & 191(78) & $36(31)$ & $10(27)$ & $237(59)$ \\
\hline 6 & Institutional Compounds & $126(51)$ & $41(35)$ & $15(41)$ & $182(46)$ \\
\hline 7 & Cemetery and religious yards & $114(46)$ & $45(38)$ & $17(46)$ & $176(44)$ \\
\hline 8 & Natural and Semi-Natural Area & $130(53)$ & $5345)$ & $12(32)$ & 195(49) \\
\hline 9 & Roadsides green spaces & $143(58)$ & $62(53)$ & $16(43)$ & $238(60)$ \\
\hline 10 & Outdoor Sport fields & $167(68)$ & $69(59)$ & $14(38)$ & $250(63)$ \\
\hline
\end{tabular}

Source: Computed by Author based on household survey data (2016) 
From Table 1, home gardens are the only green infrastructure which was visited by $62 \%$ of the respondents in Bodity town. While the others registered very low percentage of responses such as protected urban parks $(41 \%)$, green area $(32 \%)$, city square and plazas (35\%), green corridors (28\%), institutional compounds (41\%), cemetery and religious yards $(46 \%)$, natural and semi-natural areas (32\%), median and roadsides (44\%) and outdoor sport fields (39\%). Depending on the size of urban centres the development of green infrastructure varied in each urban centre. The utilisation of urban green infrastructure was influenced by different socio-economic, cultural and political factors, the development of the city/town, the available resources, especially tourist attraction sites and other recreational centres (Tamirat, 2008; Abebe, 2009; Habitamu, 2011).

This study also confirmed that availability of facilities, attractiveness, safety and other public services make a difference in the frequency of visits of green infrastructure in the study area. In general, green corridors (Lake Hawassa shores) in Hawassa city, urban parks in Wolayita Sodo and home garden in Bodity town where the most utilised and visited green infrastructure types. However, cemetery and religious yards, institutional compounds and natural and seminatural area were the least visited/utilised green infrastructure types in the study area.

Based on the ANOVA statistics result, there was a statistically significant $(p=0.000)$ difference in the utilisation of green infrastructure by respondents among the three urban centres. However, in the analysis of variance, it helps to know the overall significant variation among urban centres, but it could not reveal which of the specific urban centre differed from others. Thus, Tukey Post-Hoc Test was used to find out the difference of urban centres in the multiple comparison tables. Based on Post-Hoc Test there is a statistically significant difference in the utilisation of green infrastructure in between Hawassa city and Wolayita Sodo $(p=0.017)$, as well as between Hawassa and Bodity town $(p=0.000)$. However, there was no significant difference between Wolayita Sodo and
Bodity town $(p=0.113)$. In general, there is a statistically significant difference among the three urban centres as determined by one-way ANOVA F (2, 27) $=12.750, p=0.000$ ). A Post-hoc comparisons using the Tukey HSD test indicated that, the mean score for Hawassa $(M=63.60, S D=10.824)$ was significantly different from Wolayita Sodo $(\mathrm{M}=49.70, \mathrm{SD}=$ 11.126) and Bodity town $(\mathrm{M}=39.90, \mathrm{SD}=9.632)$. However, as illustrated in Table 2, there is no statistically significant difference in mean scores between Wolayita Sodo and Bodity town.

Patterns of Visitors to Urban Green Areas or Parks in Hawassa City: As presented in Table 2, Hawassa city majority ( $86 \%$ ) of the residents visited the surrounding green areas or parks which are nearest to their home. However, due to lack of green areas/parks, poor management system, and lack of facilities, some of the community members or residents travel a long distance to get recreational services. For instance, more than $50 \%$ of the respondents from the Andents resident area were travelling a long distance to get recreational activities from Lakeshores (Table 2). Because this residential area has a shortage of green infrastructure developments, while the Lakeshore has better recreational facilities than others (Table 2). Studies conducted by Nigatu et al. (2014) revealed that green areas and parks are unevenly distributed across the city. More than a third $(34.6 \%)$ of the city population visited Lake Hawassa shores every day, especially on weekends when the area is usually very busy with local users and tourists. Hawassa Stadium (17.9\%) was also one the main a visiting site for watching football and conducting physical exercises and recreational purposes. As presented in Table 2, Lake Hawassa shore has a lot of infrastructures that help to attract visitors from inside and outside the city. It has standard hotels, cafes, business centres, and other infrastructures like walkways, plastic and concert seats along the Lakeshore, shade trees, and lake view; it provides adequate security and overall management activity is very fascinating for visitors. While, Hawassa Stadium has different sports fields, recreational centres, small business centres, a well-protected compound with fencing tower, and security policies.

Table 2: Patterns of Visitors to Urban Green Area (parks) in Hawassa city

\begin{tabular}{|c|c|c|c|c|c|c|c|c|c|c|c|}
\hline \multirow{2}{*}{$\begin{array}{l}\text { Park/ Green } \\
\text { Areas }\end{array}$} & \multicolumn{11}{|c|}{ Number of visitors from each residential area (number and \%) } \\
\hline & Bulchana & Korem & Gebeyadar & Guwea & Piassa & Andenet & Adarie & Daka & Dato & W/tera & Total \\
\hline & $\mathrm{n}(\%)$ & $\mathrm{n}(\%)$ & $\mathrm{n}(\%)$ & $\mathrm{n}(\%)$ & $\mathrm{n}(\%)$ & $\mathrm{n}(\%)$ & $\mathrm{n}(\%)$ & $\mathrm{n}(\%)$ & $\mathrm{n}(\%)$ & $\mathrm{n}(\%)$ & $\mathrm{n}(\%)$ \\
\hline Millennium park & $0(00)$ & $0(00)$ & $0(00)$ & $0(00)$ & $0(00)$ & $0(00)$ & $3(16.7)$ & $3(7.7)$ & $5(42.9)$ & $9(33.3)$ & $26(10.6)$ \\
\hline Gudumalie park & $10(25)$ & $0(00)$ & $0(00)$ & $6(21.6)$ & $5(28.0)$ & $2(6.1)$ & $0(00)$ & $0(00)$ & $0(00)$ & $0(00)$ & $21(8.5)$ \\
\hline Guwie Park & $0(00)$ & $9(46.2)$ & $3(23.1)$ & $4(14.3)$ & $0(00)$ & $2(8.7)$ & $4(22.2)$ & $4(15.4)$ & $0(00)$ & $0(00)$ & $26(8.5)$ \\
\hline Melese park & $3(12.5)$ & $0(00)$ & $0(00)$ & $0(00)$ & $0(00)$ & $8(34.8)$ & $0(00)$ & $0(00)$ & $0(00)$ & $0(00)$ & $12(10.6)$ \\
\hline Lake shore & $11(34.4)$ & $6(23.1)$ & $6(34.6)$ & $13(46.4)$ & $11(44.0)$ & $12(17.4)$ & $6(50.0)$ & $13(42.3)$ & $5(28.6)$ & $11(22.2)$ & $85(34.6)$ \\
\hline Hawassa Stadium & $4(15.6)$ & $5(30.8)$ & $3(26.9)$ & $7(17.9)$ & $7(28.0)$ & $5(21.7)$ & $2(11.1)$ & $5(19.2)$ & $0(00)$ & $4(14.8)$ & 44(17.9) \\
\hline Guwie green area & $4(12.5)$ & $0(00)$ & $4(15.4)$ & $0(00)$ & $0(00)$ & $4(17.4)$ & $0(00)$ & $0(00)$ & $0(00)$ & $0(00)$ & $12(4.9)$ \\
\hline Data public park & $0(00)$ & $0(00)$ & $0(00)$ & $0(00)$ & $0(00)$ & $0(00)$ & $0(00)$ & $4(15.4)$ & $5(28.6)$ & $9(29.6)$ & $20(8.1)$ \\
\hline Total & $32(100)$ & $20(100)$ & $16(100)$ & $30(100)$ & $23(100)$ & $33(100)$ & $15(100)$ & $29(100)$ & $15(100)$ & $33(100)$ & $246(100)$ \\
\hline
\end{tabular}


Utilization Patterns of Urban Green Infrastructure.....

Source: Computed by Author data obtained from household survey (March 2016)

Table 2 indicates some of the green areas and parks are properly managed and maintained for visitors. Examples of these are Lakeshore, Hawassa Stadium, and Guwie parks. Others green areas are not properly handled and managed by the city authority. In general, as indicated in Table 2, 34.6\% of the sampled residents travelled to visit and recreate in the Lakeshore, while Hawassa Stadium, Millennium and Guwie parks were patronized respectively by $17.9 \%$ and $10.6 \%$ of the residents in the city. However, due to lack of facilities and security problems, Melese, Millennium and Dato parks have very patronage of visitors as compared to other main green areas or parks in the city (Table 2). In this park, there are no facilities like hotel, restaurants and other essential infrastructure developments. There are serious security problems because all the parks are located at the border of the city.

Patterns of Visitors to Urban Green Areas or Parks in Wolayita Sodo: As illustrated in Table 3, Junior Park is the most visited places in Wolayita Sodo town. About $31.6 \%$ of the respondents visit and spend their time in this park. The park provides good recreational facilities, which are secured and properly managed and suitable for visitors to enjoy themselves and visit frequently. In this park, domestic and wild animals like dogs and hyenas are kept together. There are also amazing features that visitors would like to visit. These include scenic topographic features, crocodile and fish farm, good security, management and maintenance activities. However, the park is too distant from the centre of the town. Public Garden is another place that most of the town and traveller visitors chose to recreate. As presented in Table 3, it has good and standard hotels, cafes, business centres, walkways, seats with shade trees. There were no security threats, it has very attractive green gardens, beautiful ornamental tree, erected monuments and good environment. Sodo Stadium also attracted and hosted the majority of the residents as a recreational centre in the town. However, due to management and maintenance problem, distance, security, and lack of availability of facilities, Melese, Damota parks and Arada green area did not frequently visited by the residents. Table 3 indicated the pattern of visitors in the surrounding green areas and parks.

Table 3: Patterns of Visitors to Urban Green Areas/Parks in Wolayita Sodo

\begin{tabular}{|c|c|c|c|c|c|c|c|c|c|}
\hline \multirow{3}{*}{ park /green areas } & \multicolumn{9}{|c|}{ Number of visitors from each resident area (number and \%) } \\
\hline & Damota & Hiberet & Selam & Wadu & Merkato & Kidanmheret & Fana & Golla & Total \\
\hline & $\mathrm{n}(\%)$ & $\mathrm{n}(\%)$ & $\mathrm{n}(\%)$ & $\mathrm{n}(\%)$ & $\mathrm{n}(\%)$ & $\mathrm{n}(\%)$ & $\mathrm{n}(\%)$ & $\mathrm{n}(\%)$ & $\mathrm{n}(\%)$ \\
\hline Junior park & $5(29.4)$ & $3(21.4)$ & $6(35.3)$ & $5(35.7)$ & $6(33.3)$ & $3(27.3)$ & $3(23.1)$ & $6(37.5)$ & 37(31.6) \\
\hline Public Garden & $0(00)$ & $4(28.6)$ & $3(17.6)$ & $4(28.6)$ & $0(00)$ & $2(18.2)$ & $3(23.1)$ & $3(13.8)$ & 19(16.2) \\
\hline Wolayita stadium & $3(17.6)$ & $4(28.6)$ & $4(23.5)$ & $3(21.4)$ & $5(27.8)$ & $4(36.4)$ & $5(38.5)$ & $4(25)$ & $32(27.4)$ \\
\hline Millennium park & $2(11.8)$ & $3(21.4)$ & $4(23.5)$ & $0(00)$ & $3(16.7)$ & $1(9.1)$ & $2(15.4)$ & $2(12.5)$ & $17(14.5)$ \\
\hline Melese park & $6(35.3)$ & $0(00)$ & $0(00)$ & $0(00)$ & $0(00)$ & $0(00)$ & $0(00)$ & $1(6.25)$ & $7(5.98)$ \\
\hline Arada Green area & $1(5.9)$ & $0(00)$ & $0(00)$ & $2(14.3)$ & $0(00)$ & $1(9.1)$ & $0(00)$ & $0(00)$ & $4(3.41)$ \\
\hline Total & 17(100) & $14(100)$ & $17(100)$ & $14(100)$ & $18(100)$ & 11(100) & $13(100)$ & $16(100)$ & $117(100)$ \\
\hline
\end{tabular}

Table 3 indicates that $31.6 \%$ of the sample residents in Wolayita Sodo town were visiting Junior Park, whereas, $27.4 \%$ and $16.2 \%$ of the residents visited outdoor fields (Sodo stadium) and public garden respectively in Wolayita Sodo town. Only $3.42 \%$ and $5.98 \%$ of the residents visited Arada green area, Damota and Melese Parks respectively in the town. In Wolayita Sodo town, most of the residents prefer to visit outdoor sports fields, roadside and green area. Outdoor sports fields and green areas were the most visited green infrastructure in the town. However, institutional compounds and city squares were also visited by a smaller population of residents in the town.

Patterns of visitors to urban green areas or parks in Bodity town: Visitors in Bodity town were concentrated in outdoor sports fields or recreational activities (Table 4). Bodity Stadium was used as a recreational centre for the majority of the residents in the town, followed by
Youth Centre. However, due to lack of green infrastructure development in the town, the majority of the urban communities was spending their time on common recreational areas. The Millennium and Melese parks were situated at relatively distant places in the town and were not patronized by a majority of the residents. As Table 4 indicates, Bodity Stadium (outdoor sports fields) was visited by $32 \%$ of the residents in the town. The Youth recreational centre was visited by $29.7 \%$ of the residents; Methara and Millennium Park were visited by $16.5 \%$ and $16.2 \%$ of the residents respectively (Table 4). Melese Park only hosted $5.4 \%$ of the residents and recorded the least patronage in the town. People who live in the Tembahoo area travel a long distance to access Parks/green areas than others. However, regardless of the proximity to green areas/parks, people who live in condominium only Youth Recreational Centre and Bodity Stadium (Table 4). 
Utilization Patterns of Urban Green Infrastructure.....

\begin{tabular}{l} 
Table 4: Patterns of Visitors to Urban Green Area (parks) in Bodity town \\
\begin{tabular}{|l|l|l|l|l|l|}
\hline \multirow{2}{*}{ Park /green areas } & Number of visitors from each residential area (number and \%) \\
\cline { 2 - 7 } & Telesefer & Methara & Condominium & Tembahoo & Total \\
\hline Melese Park & $1(11.1)$ & $1(11.1)$ & $0(00)$ & $0(00)$ & $\mathbf{2 ( 5 . 4 )}$ \\
\hline Youth's Rec.Center & $2(22.2)$ & $2(22.2)$ & $4(50)$ & $3(27.3)$ & $\mathbf{1 1 ( 2 9 . 7 )}$ \\
\hline Methara Green Area & $0(00)$ & $4(44.4)$ & $0(00)$ & $2(18.2)$ & $\mathbf{6 ( 1 6 . 2 )}$ \\
\hline Bodity Stadium & $3(33.3)$ & $2(22.2)$ & $4(50)$ & $3(27.3)$ & $\mathbf{1 2 ( 3 2 . 4 )}$ \\
\hline Millennium Park & $3(33.3)$ & $0(00)$ & $0(00)$ & $3(27.3)$ & $\mathbf{6 ( 1 6 . 2 )}$ \\
\hline Total & $\mathbf{9}(\mathbf{1 0 0})$ & $\mathbf{9}(\mathbf{1 0 0})$ & $\mathbf{8 ( 1 0 0 )}$ & $\mathbf{1 1}(\mathbf{1 0 0})$ & $\mathbf{3 7 ( 1 0 0 )}$ \\
\hline
\end{tabular} \\
\hline
\end{tabular}

In general, as the information obtained from city/towns municipality annual reports revealed that even though the existing green infrastructure development activities are very limited, there is high demand of recreational areas. Thus, in all the case study area the urban communities more frequently visited few, but common green infrastructure types. These are outdoor sports fields, green areas (recreational sites), roadside and green corridors, especially Lake Hawassa shores.

Frequency of Visit to Green Infrastructure: The frequency of visits to green infrastructure was analysed using the number of visits of respondents per month. Table 5 shows the monthly frequency and pattern of visitors to use green infrastructure for recreation and other purposes in the study area. The majority of the respondents has a relatively good frequency of visits to green infrastructure in the study area. In Hawassa city $30 \%$ and $24 \%$ of the respondents, respectively visited twice and three times per month. Whereas, $30 \%$ and $29 \%$ of the respondents, respectively in Wolayita Sodo visited one and two times per month. On the other hand, in Bodity town equal $22 \%$ of the respondents visited two and three times per month (Table 5). In general, $28.75 \%$ and $23.75 \%$ of respondents visit green infrastructure three times a month in the entire study area; while $11.3 \%$ and $5.5 \%$ of respondents, respectively visited four and five times a month. The remaining $21 \%$ of respondents visited only one time a month, while $9.7 \%$ of respondents reported that they did not visit throughout a month. This indicates the frequency of visitors to access and utilise green infrastructure was varied and limited in the entire study area. The number of visitors who visit green infrastructure five times a month is less than from the number of visitors that respond no visits. This is attributed to different socio-economic factors (Table 5).

Table 5: Frequency of visitor to use green infrastructure per month

\begin{tabular}{|c|c|c|c|c|c|}
\hline \multirow{3}{*}{$\mathrm{S} / \mathrm{N}$} & \multirow{3}{*}{ Number of Visits } & \multicolumn{4}{|c|}{ Responses by Urban centres } \\
\hline & & Hawassa & W-Sodo & Bodity & Total \\
\hline & & $\mathrm{n}(\%)$ & $\mathrm{n}(\%)$ & $\mathrm{n}(\%)$ & $\mathrm{n}(\%)$ \\
\hline 1 & No Visit (0) & $32(13)$ & $3(3)$ & $4(11)$ & $39(9.75)$ \\
\hline 2 & Once Per Month (1 times) & $43(17)$ & $35(30)$ & $6(16)$ & $84(21)$ \\
\hline 3 & Twice Per Month (2 times) & $73(30)$ & $34(29)$ & $8(22)$ & $115(28.8)$ \\
\hline 4 & Three Times Per Month (3 times) & $59(24)$ & $28(24)$ & $8(22)$ & $95(23.8)$ \\
\hline 5 & Four Times Per Month ( 4 times) & $27(11)$ & $11(9)$ & $7(19)$ & $45(11.3)$ \\
\hline \multirow[t]{2}{*}{6} & More than Five Times Per Month (5 times) & $12(5)$ & $6(5)$ & $4(11)$ & $22(5.5)$ \\
\hline & Total & $246(100)$ & $117(100)$ & $37(100)$ & $400(100)$ \\
\hline
\end{tabular}

Studies conducted by Kaczynski et al. (2009), indicated that people usually recreate in the closest urban green space. The analysis result of this study confirmed that people who live close to urban parks, green areas, religious institutions, and parkland tend to frequent involvement of physical activity. Another study conducted by Shanahan et al. (2014) in Australia show usually tourists have been visiting parks near to their home than parks far from their home, which suggests that factors other than distance played a role. On the contrary, a UK based study conducted by Hillsdon et al. (2006) show that there is no significant relationship between physical activity and green space availability as measured by distance and size of urban green spaces.
Reasons for visiting green infrastructure: In order to assess the reason why people visit and/or spend tangible time on green infrastructure, three major activities were identified. These are relaxation, physical exercise and social activities. With reference to the response given in the questionnaires, the respondents identified a list of thirteen different activities that resulted in frequent visitation to green infrastructure. Table 6 , summarizes the list of activities and percentages of respondent's participation. As the table shows that, relaxing and physical activities comprise the highest percentage of user's participation in utilising green infrastructure, followed by the social activities. Relaxing and reduce 
stress, enjoy the beauty of nature, and get fresh air are the main activities among relaxation activity category (Table 6). Studies conducted in the Netherlands by Marthe (2012) indicated that as diverse as urban population is, people engage in different types of green infrastructures such as relaxing, enjoying the landscape, meeting friends, organizing picnics, jogging and playing team sports. Similarly, other studies conducted by Schipperijn et al. (2010) and Qureshi et al, (2010) indicates that the frequency at which people visit urban green infrastructure to relax, for inspiration, peace and quiet; and the distance they are willing and able to cover also varied. On the other hand, among the physical activities play sport and watch games, to improve health, and walk around the roadside green spaces are the main activities frequently practised by the community in the study area (Table 6).

\begin{tabular}{|c|c|c|c|c|}
\hline \multirow[t]{2}{*}{ Categories } & \multirow[t]{2}{*}{ Purpose of Visiting } & \multicolumn{3}{|c|}{ Responses by Urban centres } \\
\hline & & Hawassa $\mathrm{n}(\%)$ & W-Sodo $\mathrm{n}(\%)$ & Bodity $\mathrm{n}(\%)$ \\
\hline \multirow[t]{5}{*}{ Relaxing activities } & Get Fresh Air & $210(85)$ & $106(91)$ & $32(86)$ \\
\hline & Relax and Reduce Stress & $210(85)$ & 112(96) & $33(89)$ \\
\hline & Enjoy the Beauty of Nature & $169(69)$ & $99(85)$ & $23(62)$ \\
\hline & For Inspiration & $145(59)$ & $93(79)$ & $24(65)$ \\
\hline & Peace and Quite & $163(66)$ & $87(74)$ & $20(54)$ \\
\hline \multirow[t]{3}{*}{ Physical activities } & Play Sport and Watch Games & $226(92)$ & $98(84)$ & $37(100)$ \\
\hline & Walk Around the Roadside & $145(59)$ & 104(89) & $30(81)$ \\
\hline & To improve health & $187(76)$ & $85(73)$ & $19(51)$ \\
\hline \multirow[t]{5}{*}{ Social activities } & For Educational Tour & $92(37)$ & $78(67)$ & $12(32)$ \\
\hline & Meet friends & $112(46)$ & $67(57)$ & $16(43)$ \\
\hline & Enjoy family outing & $98(40)$ & $59(50)$ & $22(59)$ \\
\hline & Attend events & $117(48)$ & $91(78)$ & $29(78)$ \\
\hline & Enjoy entertainment & $106(43)$ & $69(59)$ & $18(49)$ \\
\hline
\end{tabular}

Whereas, the social activities in which most urban communities participated in the study area were attending various events, enjoy a family outing, enjoy entertainment, meet friends, and for an educational tour. Various studies in the USA confirmed that Americans use the parks for sports activities, social and relaxing benefits, walking and jogging (Loukaitou-Sideris, 1995; Holm, 2000). A study in the United Kingdom conducted by Dunnett et al. (2002), indicated that the main reasons for visiting urban green spaces include enjoying the environment, social activities, walking, activities, passive and active enjoyment (including dog walking), and attending events.

Likewise, walking, relaxing, children, and sports activities are the main reasons for using urban parks and green spaces in Budapest (Rosenberger et al., 2009) and also to experience greenery, nature, peace and quiet, and to participate in stationary activities are the main reasons in Denmark (Holm, 2000). However, based on the level of the urban centres in which this study is conducted, there are variations in the three major activities (relaxing, physical and social activities) as well as in the listed activities in each case study urban centres.

Constraints on the Utilisation of UGI: There are a number of factors that affect utilization and visiting of urban green infrastructure development in the study area. The main problems that determine the community's utilisation and visits of green infrastructure were identified in Table 7. Based on the survey result, distance to their homes, lack of financial accounts, improper management of green infrastructure, lack of inclusiveness, shortage of time are the main constraints to visit green infrastructure in the study area (Table 7).

Table 7: Constraints on the utilization of green infrastructure

\begin{tabular}{|c|c|c|c|c|}
\hline $\mathrm{S} / \mathrm{N}$ & Major constraint or limitation & Hawassa & W-Sodo & Bodity \\
\hline 1 & Shortage of money & $48(20)$ & $23(20)$ & $4(11)$ \\
\hline 2 & Time shortage & $35(14)$ & $16(14)$ & $8(22)$ \\
\hline 3 & Lack of facilities cafe, toilet, seat, shops) & $51(21)$ & $21(18)$ & $5(14)$ \\
\hline 4 & The place is very far to visit/access & $36(15)$ & $8(7)$ & $4(11)$ \\
\hline 5 & Lack of GI availabilities in the city & $28(11)$ & $13(11)$ & $4(11)$ \\
\hline 6 & Does of considering all social groups & $19(8)$ & $17(15)$ & $7(19)$ \\
\hline \multirow[t]{2}{*}{7} & Quality and management problems & $29(12)$ & $19(16)$ & $5(14)$ \\
\hline & Total & $246(100)$ & $117(100)$ & $37(100)$ \\
\hline
\end{tabular}

green infrastructure, lack of facilities including

Even though the percentage of respondents was small, recreational facilities like cafe, toilet, seat, shops in the $21 \%$ of the respondent stated that unavailability's of 
urban green infrastructure developments are some of the constraints (Table 7). In addition to that, unbalanced demand and supply of green infrastructure development, lack of green infrastructure standards, lack of facilities and services in parks/green areas, lack of awareness of the benefit of green infrastructure, lack of skilled manpower and budget, bureaucratic working environment, unfair distribution of green infrastructure development (not inclusive and balance in all the urban communities) and poor quality and distance from home are among the contributing factors (Table 7)

Conclusion: Urban green infrastructures provide a multifunctional benefits for the urban people and the environment. This study investigates the current situation of the utilization of urban green infrastructure development at a different hierarchy of urban centres. The study helps to identify the opportunities and constraints in the visiting and utilization of green infrastructure development urban centres. The study also helps to consider the interest and preference of communities on green infrastructure planning and development. Relaxation, physical exercise and social activities are the three major activities were identified why people visit UGI.The results of our study provide a new idea for city planning, architecture, policy-makers, and managers and landscape specialists to consider the existing gaps in their future planning and development activities.

Acknowledgments: We are grateful to the Pan-African University, African Union (AU), Addis Ababa, Ethiopia for the financial support for this study. We thank all the people who participated in this research. We are also indebted to experts from Bureau of Urban Development and Housing and Municipalities in Hawassa, Wolayita Sodo and Bodity town for allowing us to visit and carry out this study on the selected urban centres and for providing marvellous experiences.

Authors contribution: Mikias Biazen Molla conceived and designed the methods, selected materials, assembled and analyzed the data, and prepared the article. C.O. Ikporukpo and C.O. Olatubara provided extensive advice on the arrangement and structure of the article as well as its contents.

Conflict of Interest: The authors declared no conflict of interest.

\section{REFERENCES}

Abebe A (2009). Analysis of the Development and Management of Green Areas in Fenote-Selam City, Amhara egion, MSc Thesis. Department of Urban Managemnt. Ethiopian Civil Service University, Addis Ababa
Assefa F. Mosse A., and Michael Y (2011). Assessment of clients' satisfaction with health service deliveries at Jimma University Specialized Hospital, Ethiopia. J. Health Sci, 21 (2): 101-109

Barton, J., \& Pretty, J (2010). What is the best dose of nature and green exercise for improving mental health? A multi-study analysis. Environmental Science and Technology, 44(10), 3947-3955.

Blanco, H., Alberti, M., Forsyth, A., Krizek, K. J., Rodriguez, D. A., and Talen, E (2009). Hot, congested, crowded and diverse: Emerging research agendas in planning. Progress in Planning, 71(4), 153-205.

Chang, C.Y. and Chen, P.K (2005). Human Responses to Window Views and Indoor Plants in the Workplace. Horticultural. Science. 2005, 40, 1354-1359.

Chiesura, A. (2004). The role of urban parks for the sustainable city. Landscape and Urban Planning, 68, 129-138.

Choumert, J., and Salanie, J (200). Provision of urban green spaces: some insights from economics. Landscape Research, 33(3), 331-345.

CSA (Central Statistical Central Statistical Agency), (2007). Population projection statistics report, Retrieved April 3, 2015, from http://www.csa.gov.et/

Dahmann, N., Wolch, J., Joassart-Marcelli, P., Reynolds, K., \& Jerrett, M (2010). The active city? Disparities in provision of urban public recreation resources. Health and Place, 16(3), 431-445.

DeGraaf, D.A.; Jordan, D (2003). Social Capital. Parks Recreation. 2003, 38, 20-27

DTLR (Department of Transport Local Government and the Regions), (2002). Green spaces, better places. Crown Copyright, London. http://www.ocs.polito.it/biblioteca/verde/taskforce/gs paces_.pdf $>$ (Accessed on 10 October 2017)

Dunnett, N. Swanwick, C. and Woolley, H. (2002). Improving Urban Parks, Play Areas and Green Spaces, London: DLTR

Dwyer, J. F., Schroeder, H. W., and Gobster, P (1991). The significance of urban trees and forests: towards a deeper understanding of values. Journal of Arboriculture, 17, 276-284.

Ernstson, H (2013). The social production of ecosystem services: a framework for studying environmental justice and ecological complexity in urbanized landscapes. Landscape Urban Planning. 109, 7-17. 
Francis, M (2006). Urban parks as community places.

Chuncheon G5 Symposium Talk Chuncheon, Korea, $<$ http://lda.ucdavis.edu/people/websites/francis/korea. pdf $>$ [Accessed on 23 November 2016)

Fuller, R. A., \& Gaston, K. J (2009). The scaling of green space coverage in European cities. Biology Letters, 5(3), 352-355.

Geis DE (2000). By design: The Disaster-resistant and Quality-of-life Community. Nat Hazard Rev., 3: 151160.

http://collaborate.extension.org/mediawiki/files/1/1b/Geis_Design-_DRC_and_quality_of_life_2.pdf. [Accessed on 20 December 2017].

Giles-Corti, B., \& Donovan, R. J. (2002). The relative influence of individual, social and physical environment determinants of physical activity. Social Science and Medicine, 54(12), 1793-1812.

Giles-Corti, B., Macintyre, S., Clarkson, J. P., Pikora, T., \& Donovan, R. J (2003). Environmental and lifestyle factors associated with overweight and obesity in Perth, Australia. American Journal of Health Promotion, 18(1), 93-102.

Guitart, D., Pickering, C., and Byrne, J (2012). Past results and future directions in urban community gardens research. Forestry and Urban Greening. 11, 364-373.

Habitamu Gagado (2013). Making Vacant Land Work: Assessment of vacant land utilisation in Wolayita Sodo town. M. A. Thesis, Ethiopian Civil Service University, Addis Ababa.

Hague, M., \& Siegel, N (2002). Municipal parks in New York City: Olmsted, Riis, and the transformation of the urban landscape, 1858-1897. In: Backhaus, G., Murungi, J. (Eds.), Transformations of urban and suburban landscapes: Perspectives from philosophy, geography, and architecture. Lexington Books, Lanham, MD, 153-191.

Hillsdon, M., Panter, J., Foster, C., and Jones, A (2006). The relationship between access and quality of urban green space with population physical activity. Public Health. 120, 1127-1132.

Holm, S (2000). Use and Importance of Urban Parks; Danish Centre for Forest. Landscape and Planning. Hørsholm, Denmark.

Hu DX, Tang J (2011). Approach to Amalgamation of Green Spaces and Emergency Shelters-Thinking after Wenchuan Earthquake. Adv. Mat. Res, 368-373:18191822 .
Jackson, L. E (2003). The relationship of urban design to human health and condition. Landscape and Urban Planning, 64, 191-200.

Jennifer R. Wolch, Jason Byrne, and Joshua P. Newell, (2014). Urban green space, public health, and environmental justice: The challenge of making cities 'just green enough. Landscape and Urban Planning, $125234-244$

Jerrett, M., McConnell, R., Chang, C., Wolch, J., Reynolds, K., Lurmann, F (2009). Automobile traffic around the home and attained body mass index: A longitudinal cohort study of children aged 10-18 years. Preventive Medicine, 50, S50-S58.

Kaczynski, A.T., Potwarka, L.R., Smale, B.J.A., and Havitz, M.E., (2009). Association of parkland proximity with the neighbourhood and park-based physical activity: variations by gender and age. Leisure Sciences 31, 174-191.

Katharine Beaney, (2009). Green spaces in the urban environment: uses, perceptions and experiences of Sheffield city centre residents, $\mathrm{PhD}$ Thesis University of Sheffield, UK.

Koizumi T, Katayama R (1996). Urban Disaster Prevention Project-A Feasibility Study of Regional Disaster Prevention for the Government of Kobe. Congress International Society for Photogrammetry and Remote Sensing XXXI, B7:.365-371.

Kong, F., Yin, H., \& Nakagoshi, N (2007). Using GIS and landscape metrics in the hedonic price modelling of the amenity value of urban green space: A case study in Jinan City, China. Landscape and Urban Planning, 79, 240-252.

Lee, A., \& Maheswaran, R (2011). The health benefits of urban green spaces: A review of the evidence. Journal of Public Health, 33(2), 212-222.

Lee, T (2001) Perceptions, Attitudes and Preferences in Forests and Woodlands. Technical Paper, 18, Edinburgh: Forestry Commission

Li J, Zhang L, Chen AJ, Guo H (2007). Discussion of the Ways of Combining the Urban Emergency Shelter and Urban Green Space Construction. Chinese Landscape Archit., 23(5):83-87 [In Chin.].

Loukaitou-Sideris, A. (1995). Urban Form and Context: Cultural Differentiation in the Uses of Urban Parks. $J$. Plan. Educ. Res. 1995, 4, 89-102.

Maas, J., Verheij, R. A., de Vries, S., Spreeuwenberg, P., Schellevis, F. G., \& Groenwe-gen, P. P (2009). 
Morbidity is related to a green living environment. Journal of Epidemiology and Community Health, 63, 967-997.

Marthe Laura Derkzen (2012). Experiencing the urban green space an exploratory study of visiting behaviour, perceptions and preferences in the urban green spaces of São Paulo, Master's Thesis Utrecht University Brazil.

Mefekir Woldegebriel (2017). Assessing Socio-Economic Impact of Rural-Urban Migration in Sodo Town, SNNPR Ethiopia. Global Journal of Human-Social Science, Volume 17.

Milton, K (2002). Loving nature: towards an ecology of emotion. Routledge, New York. P. 182.

Ohta, M., Mizoue, T., Mishima, N., \& Ikeda, M (2007). Effect of the physical activities in leisure time and commuting to work on mental health. Journal of Occupational Health, 49(1), 46-52.

Qureshi, S., J.-H. Breuste and S. J. Lindley (2010). Green Space Functionality along an Urban Gradient in Karachi, Pakistan: A Socio-Ecological Study. Human Ecology 38: 283-294.

Rosenberger, R.S., Bergerson, T.R. and Kline, J.D (2009). Macro-Linkages between Health and Outdoor Recreation: The Role of Parks and Recreation Providers. J. Parks Recreation. Admin. 2009, 27, 820.

Roy, S., Byrne, J., \& Pickering, C (2012). A systematic quantitative review of urban tree benefits, costs, and assessment methods across cities in different climatic zones. Urban Forestry and Urban Greening, 4(11), 351-363.

Saniya Tabassum1 and Faria Sharmin (2013). Accessibility Analysis of Parks in Urban Neighborhood: The Case of Dhaka. Asian Journal of Applied Science and Engineering, Volume 2, No 2 (2013) ISSN 2305-915X

Schipperijn, J (2010). Use of urban green space. Forest and Landscape Research No. 45-2010. Forest and Landscape Denmark, Frederiksberg. 155 pp.

Shanahan, D.F., Lin, B.B., Gaston, K.J., Bush, R.; Fuller, $R$ (2014). What are the role of trees and remnant vegetation in attracting people to urban parks? Landsc. Ecol. 30, 153-165.
Sister, C., Wolch, J; Wilson, J (2010). Got green? Addressing environmental justice in park provision. GeoJournal, 75(3), 229-248.

Takano, T., Nakamura, K., and Watanabe, M (2002). Urban residential environments and senior citizens' longevity in megacity areas: the importance of walkable green spaces. Journal of Epidemiology and Community Health, 56, 913-918.

Tamirat Balcha (2008). Appraisal of Housing Condition: The case of Wolayita Sodo Town. Unpublished M.A. Thesis, Ethiopian Civil Service College, Addis Ababa.

Thomas V. Perneger, Delphine S., Courvoisier, Patricia M., Hudelson, and Ange'le Gayet-Ageron (2014). The sample size for pre-tests of questionnaires. Quality of Life Research DOI: 10.1007/s11136-0140752-2

Van den Berg, A. E., Maas, J., Verheij, R. A., and Groenewegen, P. R (2010). Green space as a buffer between stressful life events and health. Social Science and Medicine, 70(8), 1203-1210.

Veitch, J., Ball, K., Crawford, D., Abbott, G. R., \& Salmon, J (2012). Park improvements and park activity: A natural experiment. American Journal of Preventive Medicine, 42(6), 616-619.

Wang X (2001). Type, quantity and layout of urban peripheral green space. J Forest Res., 12(1): 67-70.

Ward Thompson, C. AspinalI, P. BelI, S. Findlay, C. Wherrett, J. and Travlou, P. (2004). Open Space and Social Inclusion: Local Woodland Use in Central Scotland, Edinburgh: Forestry Commission

Ward Thompson, C. AspinalI, P. Bell, S. and Findlay, C (2005)' "It gets you away from everyday life": Local woodlands and community use -what makes a difference?' Landscape Research, 30, 1, pl09 -146

Wolayita Sodo Town Administration, (2011). Damota Tsedal. Wolayita Sodo Town profile, 2011. Wolaita Sodo.

World Bank, (2016). Fecal Sludge Management (FSM): Diagnostics for Service Delivery in Urban Areas, Report of an FSM study in Hawassa, Ethiopia

Young-Chang Lee and Keun-Ho Kim, (2015). Attitudes of Citizens towards Urban Parks and Green Spaces for Urban Sustainability: The Case of Gyeongsan City, Republic of Korea, Sustainability. ISSN 2071-1050. 